\title{
Panca Sradha in Forming Human Pancasila
}

\author{
Putu Ronny Angga Mahendra ${ }^{1}$ \\ \{puturonny87@gmail.com ${ }^{1}$ \} \\ Universitas Dwijendra, Indonesia ${ }^{1}$
}

\begin{abstract}
Learn Pancasila as the national ideology, whose values are described in the Pancasila principles. Pancasila is a protecting ideology for the various ideological and religious polarizations in Indonesia. The understanding of the Pancasila philosophy in the life of the community, nation and state is a paradigm. Pancasila is the source of all sources of law in Indonesia in terms of politics, socio-economics, international relations and religion. Hindu religious intention based on the Five Sradha principles are the five basic beliefs or beliefs of Hinduism that are firmly held in everyday life in society and religion. This good intention is carried out by means of devotional service, which has good provisions regarding the form of devotion, procedures for performing, prayers/mantras, the place and time of the service itself. Through devotion that is carried out correctly with understanding and implementation, it is hoped that it can strengthen sradha and bhakti (faith and piety), the quality of religion, and an increase in mental and spiritual life in the life of religion, society, nation and state.dramatically.
\end{abstract}

Keywords: Pancasila; Panca Sradha; National Ideology

\section{Introduction}

The era of modernization has brought the social conditions of Indonesian society to undergo a rapid change and foster a competition as a global citizen. This speed, of course, must be able to follow it well and wisely, without leaving what is our goal as a country which is stated in the ideals of Indonesian independence in the fourth paragraph of the preamble to the 1945 NRI Constitution. Keep up with developments without leaving a character or our identity as a great and independent nation [1].

One of the problems facing this nation is the waning spirit of nationalism and patriotism among the younger generation. We all know that the younger generation is the successor to the leadership and relay of the sustainability of the nation and country we love. Many young people are immersed in the progress and ease of globalization, perceiving foreign cultures as more modern than their own, ignoring the noble values of the nation, and the spirit of hedonism as a daily lifestyle. The role of youth is as a driving force and guardian of the much expected national development. These various problems of nationalism and nationality are caused by many young people who experience a disorientation, dislocation, and are involved in their own interests on behalf of the interests of their group or society [2].

Pancasila as the basis and ideology of the State is the result of an agreement by the founders of this nation, from Indonesia it was founded until the current global era. In the era of globalization, the role of Pancasila is of course very important as a reference in the state in facing various global challenges that continue to develop. Pancasila is very important in 
maintaining the existence of the personality of the Indonesian nation, being able to overcome the invisible limitations in globalization, so that it becomes a strong national filter. This filtration will have a positive impact on globalization, meaning that it is able to strengthen relations between nations without leaving their national identity. Meanwhile, if it does not work well, of course, it will give negative things, namely it can damage the nation's morals and the existence of Indonesian culture as a national character. Apart from being an ideology, the role of Pancasila is of course inseparable as a view of life that penetrates, inspires, and shapes Pancasila people in the life of personality, society, nation and state. Of course, this must be done by having an introduction, understanding, appreciation, practice, and selfreflection towards Pancasila itself [3]. Most important of all is the possession of a will that emerges as a person of strength and character.

As a country that believes in the Almighty God and gives its citizens the freedom to embrace religions and beliefs, of course the Indonesian people will never be separated from the religious values that are taught and adhered to [4]. It is clearly stated in the Indonesian Constitution, and the principles of Pancasila as a personality of the Indonesian nation. Every religion certainly provides a teaching that requires its people to carry out all His commands and stay away from His prohibitions on the basis of the beliefs that someone has in Indonesia. The balance of faith and piety is what differentiates this nation in seizing and filling its independence. Faith and piety have also been able to distinguish Indonesian people, as a national identity in the midst of globalization or world society. My study in this paper is of course trying to see and explain from the side of Hinduism, which of course in essence and meaning will not be much different from other religions in Indonesia.

Hindu religious intention is based on and based on the Five Sradha. Panca Sradha is a concept of life for Hindus in their life. Panca Sradha means the five basic beliefs or beliefs of Hinduism that must be firmly adhered to in religious and social life in order to realize and achieve their life goals in the world. Panca Sradha consists of Widhi Sradha, Atma Sradha, Karma Phala Sradha, Punarbhawa Sradha, and Moksa Sradha. This intention is carried out in a devotional manner which has good provisions regarding the form and form of devotional service, procedures for performing, prayers, mantras, the place and time of the devotional performance itself. Through devotional service which is carried out with proper and correct understanding and implementation, it is hoped that it can strengthen sradha and bhakti (faith and piety), the quality of religion and increase in mental and spiritual life in religion, society, nation and state.

\section{Method}

The research design used a basic qualitative. According to this basic qualitative design, it is intended to produce a deep understanding of Pancasila philosophy. This qualitative design is an approach that is generally used to understand and interpret social phenomena. This type of research is also often useful to further enhance understanding and crystallize research problems developed [5].

The data collected in this study are Balinese' perceptions of Pancasila principles. The primary data was collected from the results of filling out the questionnaire. Analytical induction techniques are used to analyze research data. Analytical induction, which is one of the typical data analysis techniques, is carried out with a stringent process in sequence to study the phenomenon under study. 


\section{Result and Discussion}

\section{Conceptions of Five Sradha and Its Relationship with Pancasila}

Etymologically, Panca Sradha consists of the word Panca which means five, and Sradha which means faith or belief [6]. It can be concluded that the Five Sradha are the five basic beliefs or beliefs of Hinduism that must be firmly adhered to in the life of religion, society, nation and state in order to achieve the goals of life in the world. The parts of Panca Sradha are as follows:

1. Believe in the existence of Ida Sang Hyang Widhi / God Almighty (Widhi Sradha) in Pancasila associated with the values of Precepts 1 (God Almighty).

2. Believe in the existence of atma (Atma Sradha), as the smallest part of God in the human body who gives life to humans so that they can carry out their life activities in achieving life goals. This concept teaches the need to position humans with one another. This part of the Five Sradha will be related to Sila 2 (Just and Civilized Humanity).

3. Believe in the existence of Karma Phala (Kharma Phala Sradha), a law of cause and effect in life from the perspective of Hinduism. Belief in Karma Phala will teach a concept of the unity of human life from one another in their lives. No one is able to live alone without the interference of others around him. This is related to the 3rd precept (Indonesian Unity) which is based on love, human affection for one another. In Hinduism, the concept of Tat Twam Asi (I am you, you are me) is taught as the basis for tolerance in our life together.

4. Believe in the existence of Punarbhawa or Samsara (Karma Phala / Samsara Sradha). The Punarbhawa Sradha gives an understanding that there is belief in rebirth from a previous life, or for the next life. In this case, a good treatment is needed in every period of life that is lived. Provides an overview of life on the basis of what has been done then, now and in the future. This can be linked to the conception of the 4th Precept (Democracy Guided by Wisdom Wisdom in Deliberation / Representation), as a reference in respecting respect, building a spirit of democracy between the leader and the people. (The Kaula Ngiras The King, The King Ngiras The Kaula).

5. Believe in the existence of Moksa (Moksa Sradha). Moksa is an achievement of life goals that every human being wants to achieve. In the dimension of Pancasila values, the goal of every human being is to achieve justice. A taste that is able to provide a comfort, even though it is still relative. This can be linked to Precept 5 (Social Justice for All Indonesians). Justice is based on the abilities and needs of every human being in achieving a level of prosperity (Gemah Ripah Toh Jinawi Tentram Kertha Raharja).

The explanations from the Panca Sradha section are as follows:

1. Widhi Sradha

Widhi Sradha is a belief or belief about the truth of the existence of Ida Sang Hyang Widhi/God Almighty. This belief can be done with the teachings of Tri Pramana, namely Religion/Sabda Pramana, Anumana Pramana, and Pratyaksa Pramana. In the Pramana religion, a person believes in the existence of God through his testimony or words conveyed through the Vedic scriptures which are bestowed on Maharsi, Yogis and wise people. In the Anumana Pramana concept, a person believes in the greatness of God through a logical and systematic analysis of what is in the universe, its events, which are God's will and creation. Meanwhile, Pratyaksa Pramana believes in the existence of God because he experiences directly, sees the manifestation of God, in people who have a high level of purity [4].

In the concept of Widhi Sradha, four sides of the omnipotence of God are also taught, called Cadhu Sakti. Cadhu Sakti consists of: Wibhu Sakti (omnipresent nature), Prabhu Sakti (omnipotent nature), Jnana Sakti (who is omniscient), Krya Sakti (who is a masterpiece). In 
Hinduism, Brahman is manifested in two attributes, namely Saguna Brahman (as a supreme person) and Nirguna Brahman (unconditioned, without nature, unthinkable and beyond the limits of the human mind's ability).

2. Atma Sradha

A belief about the existence of Atman. Atman is singular "Brahman Atman Aikyam", which means a small spark from Ida Sang Hyang Widhi / God Almighty as the source of life, which is in every living body. As for the characteristics of atma are: utterly perfect, unharmed, unburned, undrinkable, immovable, eternal, omnipresent, immovable, and always in the same state.

3. Karma Phala Sradha

A belief about the truth of the existence of karma phala or results of actions. This is what will bring our spirits after death where they will get. Everyone sees the results of their actions while humans are still alive, whether they will go to heaven or hell. There is a way to get away from the law of karma that applies and binds oneself, namely by changing all actions into yoga, surrendering everything to Ida Sang Hyang Widhi / God Almighty as the origin of everything and on his will.

There are several divisions of Karma Phala, namely: Sancita Karma Phala (past actions that have not yet been enjoyed and are still the seeds that determine our present life), Prarabda Karma Phala (phala of our actions in this life without any remaining), and Kriyamana Karma. Phala (the results of actions that cannot be enjoyed at the time of doing things must be accepted in the next life).

4. Punarbhawa Sradha

A belief in the truth of repeated rebirths. Punar which means annihilated or lost, while bhawa which means to grow or be born. So the concept of Purnabhawa is repeated rebirth / reincarnation / rebirth / samsara. Birth is due to past karma. Punarbhawa is a suffering that results from the successive karma wasana (former deeds) of our lives. Punarbhawa makes us able to improve ourselves in order to achieve the goal of life perfection that we want.

5. Moksa Sradha

Moksa is a belief from Hinduism that deals with the truth of being free from worldly bonds, where the soul is free from the cycle of birth and death. This Moksa is the last destination of Hindus. There are four types of Moksa namely: (1) Samipya: a freedom achieved by a person during his lifetime on earth, (2) Sarupya: a freedom that is obtained by a person in this world because of his birth, where the position of Atman is an emanation of the Almighty God, (3) Salokya: a freedom that can be achieved by Atman, where Atman himself has reached the same consciousness with God, and (4) Sayujya: the highest level of freedom, where Atman is truly one with Brahman / God.

Seeing the development of modernity today, of course, people leave their identity, especially in their activities [7]. Global culture caused by modern and global life patterns, modernization in various forms of mastery of science and technology continuously follows the social development of society. Education, primarily religious education, provides an appreciation and practice of religious teachings to generations/students who become dynamic by realizing the lofty ideals of independence. Especially among the millennial generation who tend to use information technology as an existence in the current development. Therefore advances in science and technology have brought changes in people's lives where ethical and moral setbacks are owned by the younger generation. With a variety of positive activities that build awareness, one of them pasraman will be able to increase faith and belief (sradha) through Hindu-based education to minimize the negative impact arising from these changes. 


\section{The National State in the Perspective of Hinduism}

There are three types of State in relation between religion and State. First, the theocratic State, namely the State which bases its government on one particular religion. The Kingdom of Saudi Arabia, the Islamic Republic of Iran, Pakistan are some examples of countries that make Islam the basic constitutional state. The second type of State is a secular State, a State which assumes that religious affairs are the personal affairs of each citizen. Secularism is applied in Western countries such as the United States and France. The next type is Communists, who consider religion to be opium, for example China and Cuba as countries with such religious views [8].

Indonesia is a country with the largest Muslim population in the world, but it does not make Islam the basis of its country. Indonesia chose Pancasila as the philosophy of life and the basis of the State, of course this has never been separated from the long history of this nation from before independence to the time of the movement when the basic elements of the State were formulated by the founding fathers of this country. There are differences of opinion and views in the process of forming this country, until the establishment of Pancasila as a consensus agreed upon by all components of the nation from various ethnicities, religions and groups/groups.

State life, of course, can never be separated from politics. There are several political views that exist in religious teachings. Hinduism also has its own views on this politics. In Hindu literature, such as Canakya, Niti Sastra, Kekawin Ramayana, Mahabhrata, Kekawin Ramayana, Lontar Janiti, vocabulary is found relating to constitutive elements of a State such as praja, wadya (people), rat (State, people), universe, janapada, loka (state territory), prabu, queen maharaja (head of government), and so on. The aim of the State according to Hinduism is to ensure the attainment of the welfare of the people both physically and spiritually, among others are listed in Yajur Weda V.27, Atharwa Weda XIII.I.34 and Atharwa Weda XII.3.10. The relationship between religion and the State is based on a relationship of mutual respect, as depicted in wiku (religion) and natha (power) or purohito (king), which are the pillars that determine the strength of the State. Wiku gave advice to Natha regarding issues related to values, morals, and spirituality, so that the government would run according to dharma and bring prosperity to the people. This is a form of obligation (dharma) within the framework of the dharma of religion and the dharma of the State in forming smart and good citizenship [9].

The existence of the state in Hindu thought emphasizes the functionalization of the state in its concrete form, which is the government to be able to protect and regulate public order. This means Hinduism recognizes the importance of both entities, the state and society. Hindu thought about this state has relevance to democratic theories which believe in the importance of the existence of the state in relation to society. There is no democracy without a state, this Hindu thought provides a relatively moderate view of the state which prevents us from jumping from a "right" to an extreme "left" perspective. So we are heading for a situation where the state has a relative degree of autonomy. Even though in the reality of state life there is often oppression by strong groups against the weak, the state is always required to create justice and welfare for its citizens.

\section{Pancasila as the Ethical Foundation of Interfaith Studies in Indonesia}

History has proven that based on a review of philosophical and historical aspects, the birth of Pancasila is very closely related to the ethics and culture of the original Indonesian Nation. These values have developed long before Indonesia's independence. Based on historical evidence, ethics and culture have the most influence on the Indonesian nation before it developed rapidly during the Majapahit kingdom. The Majapahit Kingdom has given a 
religious nuance and a great influence on the development of Hindu culture in Indonesia. Hindu culture has given a lot of color to life and norms of behavior that are well developed in society. This can be seen based on historical evidence about Hindu culture in Indonesia [10].

To appreciate the struggle of the founders of the State who fought with all the sacrifices, body and soul, property for one purpose. Pancasila must always be understood, lived and practiced in the life of the community, nation and state because Pancasila is the nation's philosophy of life, the source of all sources of law, and Pancasila is the foundation of the Republic of Indonesia. Ontologically, the unity of the Pancasila principles as a pyramidal hierarchical form is described as follows: (1) The 1st precept, that in essence the existence of God is because of Himself, God is causa prima. This means that everything that exists, including humans, exists because God created it, (2) The second precept, humans as the principal of a country, then a state appears, which is a community of living together with human members, (3) The 3rd precept, the State is the result of human beings who are united, (4) The fourth precept, the result of a united human being, will form people who are the elements of a country besides territory and government. In other words, the people are the totality of the individuals in the united State, and (5) The fifth precept, with the formation of a government, a goal will emerge, namely justice, which is the essence and purpose of the institution of living together called the State.

\section{Conclusion}

This The belief in the teachings of Hinduism in Pancasila as a unity of precepts which has a complete and unified unity in order to be carried out harmoniously and completely as well. Pancasila has a very noble and noble value in universal human life. Pancasila as the national ideology, whose values are described in the Pancasila principles. Pancasila is a protecting ideology for the various ideological and religious polarizations in Indonesia. The understanding of the Pancasila philosophy in the life of the community, nation and state is a paradigm. Pancasila is the source of all sources of law in Indonesia in terms of politics, socioeconomics, international relations and religion. Hindu religious intention based on the Five Sradha principles are the five basic beliefs or beliefs of Hinduism that are firmly held in everyday life in society and religion. This good intention is carried out by means of devotional service, which has good provisions regarding the form/form of devotion, procedures for performing, prayers/mantras, the place and time of the service itself. Through devotion that is carried out correctly with understanding and implementation, it is hoped that it can strengthen sradha and bhakti (faith and piety), the quality of religion, and an increase in mental and spiritual life in the life of religion, society, nation and state.

\section{References}

[1] S. Soeprapto, “ Implementation of Pancasila in National and State Life (in Bahasa)," $J$. Ketahanan Nas., vol. 15, no. 2, pp. 17-28, 2010.

[2] A. P. Asmaroini, " Keeping The Existence Of Pancasila And Its Application For The Community In The Era Of Globalization (in Bahasa)," JPK J. Pancasila dan Kewarganegaraan, vol. 2, no. 1, pp. 50-64, 2017.

[3] N. Kristiono, " Strengthening The Ideology Of Pancasila In Students Of The State University Of Semarang (in Bahasa)," Harmoni, vol. 2, no. 2, pp. 193-204, 2017.

[4] I. G. N. Santika, " Examining the Roots of the Indonesian Nation's Uprising After the Revision of the KPK Law Revised Results from the Pancasila Perspective (in Bahasa)," J. Ilm. Ilmu Sos., 
vol. 6 , no. 1, pp. 26-36, 2020.

[5] R. Lawrence, L. F. Ching, and H. Abdullah, "Strengths and weaknesses of education $4.0 \mathrm{in}$ the higher education institution," Int. J. Innov. Technol. Explor. Eng., vol. 9, no. 23, pp. 511-519, 2019.

[6] P. R. A. Mahendra, "Civic Culture Ngayah in Civics Learning (in Bahasa)," AP3KnI Jateng.Jurnal PPKn, vol. 6, no. 1, 2018.

[7] P. I. Christiawan, "Cultural Landscape: A Bridge Between Deforestation and Local Community?," J. Landsc. Ecol., vol. 11, no. 2, pp. 77-87, 2018.

[8] P. R. A. Mahendra, “ PPKn Learning in National Resonance and Globalization (in Bahasa),” $J$. Ilm. Ilmu Sos., vol. 4, no. 2, pp. 120-126, 2018.

[9] A. Widiyanta, “ Attitudes Toward Environment and Religiosity (in Bahasa)," Psikologia, vol. I, no. 2, pp. 86-95, 2005.

[10] I. K. Sardiana and K. K. Dinata, " Study of Plant Utilization in Ritual Activities (Upakara) by Hindus in Bali (in Bali)," J. Bumi Lestari, vol. 10, no. 1, pp. 123-127, 2010. 